\title{
Prevalence of occult HCV infections in Saudi patients who achieved sustained virologic response with direct acting antiviral treatment
}

\author{
Hamad Al Ashgar ${ }^{1}$, Ahmed AIQahtani ${ }^{2}$, Mohammed Al Quaiz ${ }^{1}$, \\ Hussa Alhussaini ${ }^{3}$, Khalid Al Kahtani ${ }^{1}$, Amr M Elssadany ${ }^{4}$, Saleh A Alqahtani ${ }^{5}$, \\ Musthafa Chalikandy Peedikayil ${ }^{1 *}$. \\ ${ }^{1}$ Medicine, Gastroenterology dept., King Faisal Specialist Hospital \& Research Center, Riyadh, Saudi \\ Arabia, ${ }^{2}$ Infection and Immunity dept., Research Center, King Faisal Specialist Hospital \& Research \\ Center, Riyadh, Saudi Arabia, ${ }^{3}$ Anatomic pathology, King Faisal Specialist Hospital \& Research Center, \\ Riyadh, Saudi Arabia, Radiology dept., King Faisal Specialist Hospital \& Research Center, Riyadh, Saudi \\ Arabia, ${ }^{5}$ Consultant hepatologist, King Faisal Specialist Hospital and Research Centre. Riyadh. Saudi \\ Arabia. \\ *musthafacpdr@gmail.com
}

Received: $17-6-2020$

Accepted: $13-8-2020$

\section{Abstract}

Background: Occult hepatitis $\mathrm{C}$ virus (HCV) infection (OCI) is a condition where HCVRNA is present in hepatocytes or peripheral blood mononuclear cells (PBMCs), but not in the serum, in patients treated for hepatitis $\mathrm{C}$ infection. Serum HCV antibodies may or may not be present. Aim: We investigated the prevalence of OCI in PBMCs and hepatocytes in patients who had achieved sustained virologic response (SVR) after 24 weeks of directacting antiviral treatment. Methods: Chronic HCV patients with Genotype 1a and 4 who achieved SVR24 weeks after treatment with direct-acting antiviral agents (DAAs) were prospectively selected. RNeasy Blood and Tissue Kit (Qiagen $\mathrm{GmbH}$, Germany) was used for RNA extraction from blood and liver tissue samples. Superscript IV First-Strand Synthesis System (Invitrogen) was used for reverse transcription PCR. Quantitative and qualitative detection of HCV RNA was performed using primers specific to the 5'untranslated region (5'UTR). Patients: Of the six chronic HCV patients recruited for this study, five were infected with genotype 4 and one with genotype 1a. Five patients were treated with Sofosbuvir and Daclatasvir, and one patient with Ledipasvir plus Sofosbuvir. All of the patients were immunocompetent. Results: None of the patients had detectable HCV RNA in either the PBMCs or hepatocytes, suggesting zero prevalence of OCI in patients who achieved 24 weeks SVR post DAA treatment. Conclusion: We failed to detect HCV RNA in both the hepatocytes and PBMCs of all patients recruited for the study. This finding suggests that $\mathrm{OCI}$ is a rare phenomenon in chronic HCV patients with SVR following DAAs.

Keywords: Chronic hepatitis, $\mathrm{HCV}$, hepatitis C virus, occult infection, occult $\mathrm{HCV}$ infection, direct-acting antiviral agents.

\section{Introduction}

Around 160 million people are infected with hepatitis $\mathrm{C}$ virus (HCV) worldwide ${ }^{1}$. In Saudi Arabia, approximately100,000 to 280,000 people have HCV infection with an estimated prevalence of anti-HCV antibodies of $1.08 \%(0.97-1.19 \%)$ among people aged $\geq 15$ years and $0.19 \%$ among children, based on expert consensus. The viremic prevalence among all ages is $0.5 \%(0.4-1.3 \%)^{2}$. Because of their efficacy, ease of use, and tolerability, direct-acting antiviral agents (DAAs) remain the only standard care of treatment for chronic HCV infection ${ }^{1}$. The diagnostic parameters used to confirm when a patient is cured of HCV include the absence of HCV RNA in blood 12 weeks posttreatment with DAAs ${ }^{1}$. Studies have shown that treatment with the currently available DAAs could successfully achieve sustained virologic response (SVR) in more than $95 \%$ of patients ${ }^{3}$. However, few patients present a condition called occult HCV infection (OCI), where HCV RNA is detected in hepatocytes or peripheral blood mononuclear cells (PBMCs) but not in the serum, with or without the presence of serum HCV antibodies, after treatment with DAAs. A few studies reported the prevalence of OCI in a smaller percentage of patients treated for $\mathrm{HCV}$ infection with pegylated interferon and ribavirin, who tested negative for serum HCV RNA both in the presence or absence of serum HCV antibodies ${ }^{4,5}$. OCI has been primarily detected in patients with cryptogenic liver cirrhosis ${ }^{6}$. Moreover, people cured of $\mathrm{HCV}$ infection could have late relapse infections, and sometimes relapse was observed after a few months to years after SVR, suggesting OCI to be a clinically significant occurrence $^{7}$. The extent of HCV relapse due to OCI, patient-to-patient transmission of OCI, and possible progression of OCI to liver cirrhosis and hepatocellular carcinoma in patients has not been well studied and requires further research. Although 
OCI was reported in the era of interferon and ribavirin treatment, its clinical relevance after the introduction of DAA has not been thoroughly investigated. Recent studies on explanted livers following liver transplantation demonstrated the prevalence of OCI in patients treated with DAA after having $\mathrm{SVR}^{8-10}$. Another study reported the presence of OCI in PBMCs after achieving SVR post DAA treatment ${ }^{10}$. These studies show the varying occurrence of OCI in patients who have achieved SVR post DAA treatment. In Saudi Arabia, a national program for $\mathrm{HCV}$ elimination was launched last year. The objective of the program was to implement efficient treatment methods to cure HCV infections in patients from Saudi Arabia; thus, it is critical to know if OCI exists in patients who achieved SVR after treatment. To our knowledge, there is no data available or published work addressing OCI in Saudi patients. The current study is a pilot analysis to study OCI in chronic HCV patients from Saudi Arabia, who achieved SVR of 24 weeks post-treatment with DAAs.

\section{Materials and Methods}

\section{Study design}

This was a descriptive cross-sectional survey.

\section{Study Area}

The study was performed in patients from Saudi Arabia, who underwent treatment at the $\mathrm{HCV}$ clinic at King Faisal Specialist Hospital and Research Center, Riyadh, between $15^{\text {th }}$ October 2017 and $11^{\text {th }}$ March 2018. Hepatologists conducted the study in collaboration with the Department of Research, the Department of Pathology, and the Department of Radiology at the King Faisal Specialist Hospital and Research Center. The research promotion committee at the Department of Medicine and Department of Research Advisory Council and Ethics at the King Faisal Specialist hospital approved the study in July 2017 (RAC number \#2171098). All patients included in the research consented to be studied and were counseled accordingly.

\section{Study population}

All patients recruited for this study had prior chronic HCV infection and were treated with DAA, who subsequently achieved SVR at 12 and 24 weeks. No HCV RNA was detected in blood samples at 12- and 24-weekspost-DAA treatment. The patients had a fibrosis score of F1 to F3 on fibroscan. Pregnant, lactating women, patients with thrombocytopenia (values of less than 50,000 platelets $/ \mu$ l of blood and coagulopathy with international normalized ratio (INR) >1.5), patients who had a infection of both HCV and HIV, and patients who had recent organ transplantation were not included in the study.

\section{Specimen collection and isolation of PBMCs from blood samples}

After collecting the relevant information and explaining to the patients the aim of the study and the test procedures, blood samples were collected aseptically in tubes containing ethylene diamine tetra acetic acid (EDTA). PBMCs were isolated following standardized protocols.

\section{Liver biopsy}

The patients underwent transcutaneous liver biopsy guided by ultrasound done by a licensed radiologist and following the accepted guidelines ${ }^{11}$, after obtaining consent from the patients. The length of liver tissue harvested from the liver biopsy was $5 \mathrm{~mm}$ and was performed using a Tru-Cut needle biopsy. Two tissue specimens were harvested from each patient, one collected in formalin solution for analysis at the pathology department and another in RNA stabilization reagent (Qiagen GmbH, Germany) for HCV RNA detection at the research department.

\section{RT-PCR and RNA isolation from PBMCs and hepatocytes}

RNA was extracted and purified from PBMCs and hepatocytes (harvested from liver tissues following the standardized protocol) using RNeasy Blood and Tissue Kit (Qiagen GmbH, Germany). Reverse transcription PCR (RT-PCR) of the RNA extracted from the samples was done following previously standardized protocols ${ }^{12}$. RT-PCR of the RNA was performed using the superscript IV first-strand synthesis system (Invitrogen Life Technologies, Carlsbad CA, USA) to synthesize complementary DNA (cDNA), and quantitative and qualitative detection of $\mathrm{HCV}$ RNA PCR amplification was performed using primers specific to the $5^{\prime}$ untranslated region ( $\left.5^{\prime} \mathrm{UTR}\right)$. A product of $241 \mathrm{bp}$ was formed representing the HCV RNA.

\section{Sample size}

The current analysis is a pilot study to test the feasibility of testing for OCI by detecting the presence of HCV-RNA in hepatocytes and PBMCs using RT-PCR. Six patients were recruited for this study and provided consent for liver biopsy.

\section{Data entry}

All eligible patients were clinically assessed throughout the study period by having procedural blood tests, imaging studies, and fibroscan. The data was documented cautiously following protocols. Data from the DAA regimen, HCV RNA viral load of blood samples by RT-PCR, HCV genotype, liver biopsy with the grading of inflammation and staging of fibrosis (Metavir score), and the results of $\mathrm{HCV}$ RNA by RT-PCR from PBMCs and hepatocytes were also cautiously documented. 


\section{Statistical data analysis}

Based on the data acquired, categorical variables were analyzed using numbers, ratios, and frequency tables. For discrete variables and continuous variables, mean, median, range, and standard deviation were analyzed. A Chi-square test was used to study the relationship between two categorical variables. When one or more cells had an expected frequency of five or less, Fischer's exact test was used for the analysis. For two independent groups, an independent samples t-test was used to compare the mean of normally distributed interval dependent variables.

\section{Results}

A total of six patients were recruited for this study, out of which five were males, and one was a female with a mean age of 42.3 years. The data from peripheral blood RT-PCR obtained from all six patients, and hepatocytes RT-PCR obtained from five patients was analyzed. Liver function tests performed during liver biopsy had a mean alanine aminotransferase (ALT) value of $16.8 \mathrm{IU} / \mathrm{ml}$ (ALT in the recruited patients were normal at the time of liver biopsy). Five patients were treated with a combination of daclatasvir and sofosbuvir, and one patient was treated with sofosbuvir and ledipasvir. Five patients were genotype 4, and one was infected with genotype 1a. Baseline characteristics of the recruited patients who underwent either liver biopsy or blood tests are shown in tab. (1). None of the patients showed any complications due to liver biopsy. Each patient's HCV viral load before the initiation of DAA treatment and at the time of liver biopsy are given in the table with title baseline characteristics. The liver biopsy findings were assessed by Metavir scoring system; histology of the liver tissue showed fibrosis ranging from stage I to stage III; inflammatory activity in the liver biopsy ranged from grade 0 to grade 3 . HCV viral load in patients was in the range from 0.37 million $\mathrm{IU} / \mathrm{ml}$ copies to 43.3 million IU/ml copies. RT-PCR results of PBMCs and hepatocytes isolated from patients showed no presence of HCV RNA in any of the samples, fig. $(\mathbf{1} \& \mathbf{2})$. The prevalence of OCI among the recruited patients was zero. Further statistical calculations were not performed because of a lack of evidence of OCI prevalence.

Table 1. Characteristics of the patients who were involved in the studv.

\begin{tabular}{|c|c|c|c|c|c|c|c|c|c|}
\hline Case & $\begin{array}{c}\text { Post } \\
\text { Treatment } \\
\text { Liver } \\
\text { biopsy }\end{array}$ & $\begin{array}{c}\text { Post } \\
\text { Treatment } \\
\text { blood } \\
\text { sample } \\
\text { tested }\end{array}$ & $\begin{array}{c}\text { HCV Q } \\
\text { before the } \\
\text { DAA } \\
\text { treatment }\end{array}$ & $\begin{array}{c}\text { HCV Q } \\
\text { before the } \\
\text { Liver } \\
\text { biopsy }\end{array}$ & $\begin{array}{c}\text { Liver } \\
\text { biopsy } \\
\text { grading } \\
\text { and staging }\end{array}$ & Genotype & $\begin{array}{l}\text { Direct- } \\
\text { acting } \\
\text { antiviral } \\
\text { agents }\end{array}$ & $\begin{array}{c}\text { HCV from } \\
\text { WBC by } \\
\text { RT PCR }\end{array}$ & $\begin{array}{l}\text { HCV } \\
\text { from the } \\
\text { liver } \\
\text { tissue by } \\
\text { RT PCR }\end{array}$ \\
\hline 1 & Done & Done & 409179 & 0 & $\mathrm{~F} 0, \mathrm{~S} 1$ & 4 & $\begin{array}{l}\text { Sofosbuvir } \\
\text { and } \\
\text { Daclatasvir }\end{array}$ & Negative & Negative \\
\hline 2 & Done & Done & 43318145 & 0 & $\mathrm{~F} 1, \mathrm{~S} 1$ & 4 & $\begin{array}{l}\text { Sofosbuvir } \\
\text { and } \\
\text { Daclatasvir }\end{array}$ & Negative & Negative \\
\hline 3 & Done & Done & 2131441 & 0 & $\mathrm{~F} 1, \mathrm{~S} 1$ & 4 & $\begin{array}{l}\text { Sofosbuvir } \\
\text { and } \\
\text { Daclatasvir }\end{array}$ & Negative & Negative \\
\hline 4 & Done & Done & 373320 & 0 & $\mathrm{~F} 0, \mathrm{~S} 1$ & 4 & $\begin{array}{c}\text { Sofosbuvir } \\
\text { and } \\
\text { Daclatasvir }\end{array}$ & Negative & Negative \\
\hline 5 & Done & Done & 4529417 & 0 & $\mathrm{~F} 3, \mathrm{~S} 3$ & $\mathrm{la}$ & $\begin{array}{c}\text { Ledipasvir } \\
\text { plus } \\
\text { Sofosbuvir }\end{array}$ & Negative & Negative \\
\hline 6 & Not done & Done & 373467 & 0 & $\begin{array}{l}\text { Liver } \\
\text { biopsy not } \\
\text { done }\end{array}$ & 4 & $\begin{array}{c}\text { Sofosbuvir } \\
\text { and } \\
\text { Daclatasvir }\end{array}$ & Negative & $\begin{array}{l}\text { Not } \\
\text { done }\end{array}$ \\
\hline
\end{tabular}

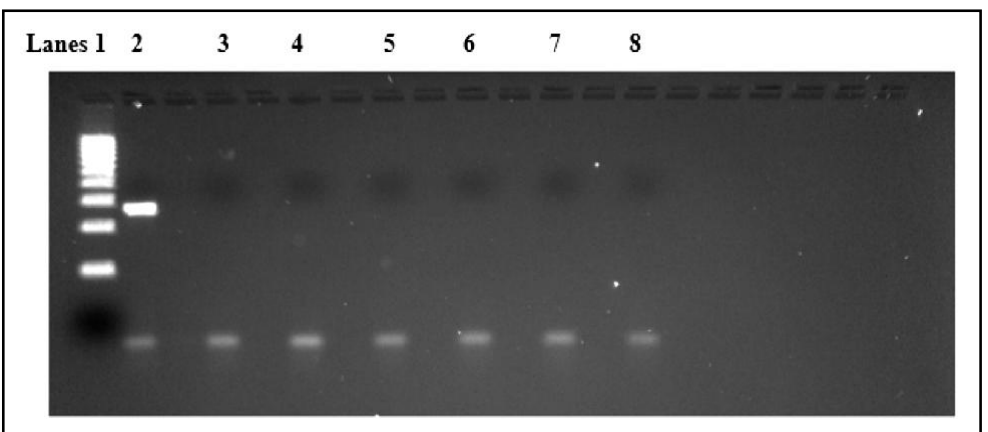

Figure 1. HCV RNA detected by reverse transcription PCR were negative in the hepatocytes of all five tested patients. Lane 1, DNA molecular weight; lane 2, HCV RNA positive control; lanes 3-8, patient samples. 


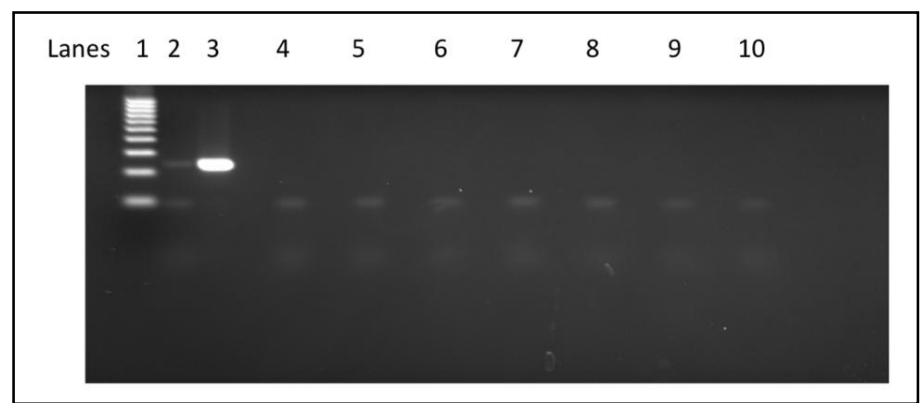

Figure 2. HCV RNA detected by reverse transcription PCR were negative in the peripheral blood mononuclear cells of all six patients. Lane 1, DNA molecular weight; lane 2, HCV RNA positive control; lanes 3-10, patient samples.

\section{Discussion}

Occult HCV infection (OCI) is a relatively new phenomenon identified in the last decade ${ }^{13}$. OCI is described as a condition where HCV RNA is detected in the hepatocytes or PBMCs, but not in the serum, with or without serum HCV antibodies. The current analysis was done to investigate the prevalence of OCI in both PBMCs and heaptocytes in chronic $\mathrm{HCV}$ patients treated with DAAs who achieved SVR at 24 weeks posttreatment. We found that, post-DAA treatment 24 weeks SVR, none of the patients had evidence of OCI in either PBMCs or hepatocytes. At present, OCI is observed in three different clinical settings: serum negative HCV RNA and HCV antibodies with consistently elevated liver enzymes and detectable HCV RNA in the liver tissue or PBMCs; serum negative $\mathrm{HCV}$ RNA and serum positive $\mathrm{HCV}$ antibodies with normal liver enzymes and detectable HCV RNA in the liver tissue or PBMCs; serum negative HCV RNA and serum positive HCV antibodies, with abnormal liver enzymes and detectable HCV RNA in the liver tissue or PBMCs ${ }^{4,5,13}$. Multiple studies have suggested that HCV RNA in PBMCs might act as an extrahepatic site for HCV replication ${ }^{8}$. Also, study findings support the notion that OCI is a potential culprit in cryptogenic liver disease. OCI in cryptogenic liver cirrhosis has been reported to range between $8.9 \%$ and $40 \%$ in PBMCs and between $0 \%$ and $50 \%$ in heaptocytes $^{6}$. During the period when interferons, including pegylated interferon and ribavirin, were used to treat chronic hepatitis $\mathrm{C}$ infections, several studies reported the presence of viable $\mathrm{HCV}$ genome in PBMCs and hepatocytes in patients, many years after treatment. The patients were considered to be clinically cured of HCV infection, confirmed by the absence of HCV RNA in the serum ${ }^{5,6,14}$. Extremely low levels of viral particles, levels under the detection limit of conventional RT-PCR, could account for why no HCV RNA was detected in the serum of patients who had viable virus particles in the liver and PBMCs ${ }^{9}$. A study by
Gamabato et al. analyzed HCV RNA in the liver explants of 39 patients treated with an interferonfree regimen", with only $6(15 \%)$ patients finalized for the treatment course at the time of liver transplantation. HCV RNA was detected and quantified in 26/39 liver explants (67\%), and most patients in the cohort were treated with sofosbuvir and ribavirin. The presence of HCV RNA in the liver explants showed no association with virologic relapse after transplantation, except in patients with elevated levels of HCV RNA? ${ }^{9}$. A study similar to the current analysis, by Yousif et al., on the prevalence of OCI in PBMCs in patients who were treated with DAA with an SVR of 12-24 weeks post-DAA treatment, reported an OCI rate of $11.33 \%$ in PBMCs. However, none of the patients underwent a liver biopsy to detect OCI in their hepatocytes ${ }^{\mathbf{1 0}}$. Another study by Elmasry et al. identified a cohort of 14 post-liver transplant patients who were treated with DAA and achieved SVR. However, the levels of serum aminotransferases failed to normalize during or after DAA therapy or normalize transiently but elevated rapidly post-DAA therapy. Nine out of 14 patients had a liver biopsy and were tested for OCI by RT PCR. Out of the nine patients, five patients $(55 \%)$ were found to have OCI infection ${ }^{8}$. Wang et al, from China studied 140 subjects, and from them 16 had features of occult HCV (11.4\%); and 60 patients from 140 had treatment with DAA, and 9 $(15 \%)$ of them showed features of occult $\mathrm{HCV}^{11}$. A study from Iran, 161 intravenous drug users with HIV infection were enrolled. These subjects were screened for $\mathrm{HCV}$ infection and 27 patients were found anti-HCV negative in the serum and negative HCV RNA in the plasma, and from these 27 subjects $5(18.5 \%)$ of the patients were found to have occult $\mathrm{HCV}$ from the PBMCs. OCI was tested by looking for HCV RNA in PBMCs ${ }^{12}$. Another study from Iran enrolled HIV-infected 190 Iranian individuals, and they were tested for occult HBV and occult HCV by doing Viral RNA 
and DNA extraction from plasma and PBMC specimens, and the presence of HCV-RNA in plasma and PBMC samples was tested using reverse transcriptase-nested polymerase chain reaction (PCR), HBV viral load was determined in plasma samples using COBAS TaqMan $48 \mathrm{Kit}$, and also the presence of the HBV-DNA in PBMC samples was tested by real-time PCR. In this study, the prevalence of OBI and OCI in HIV-infected individuals was $3.1 \%$ and $11.4 \%$, respectively ${ }^{\mathbf{1 3}}$. Contrary to the results from these two studies, our study showed no patients to have OCI infection with no detectable HCV RNA in either the PBMCs or liver tissue after achieving SVR of 12-24 weeks post-DAA treatment tab. (3). It is critical to note that all patients in this study were immunecompetent, in contrast to the post-liver transplant patients studied by Elmasry et al. ${ }^{8}$. Also, the study by Yousif et al. analyzed OCI only in PBMCs, and none of the patients underwent a liver biopsy to detect OCI in the liver tissue ${ }^{\mathbf{1 0}}$. The clinical significance of OCI observed by Yousif et al. and Elmasry et al. are still unknown ${ }^{8,10}$. Based on the results reported by Elmasry et al., OCI testing can be recommended to patients who have SVR with persistently elevated aminotransferases or fluctuating aminotransferases ${ }^{\mathbf{8}}$, but further investigation is warranted to validate this. A limitation of the current study is its small sample size, with only six patients in total. However, the fundamental approach of this investigation was to understand the concept of occult HCV in a Saudi population analyzed in both PBMNCs and liver tissue. Further research is required in a more extensive group of patients, and further validation in the future could help develop screening tests for occult $\mathrm{HCV}$ in individuals who have SVR and are potential organ and blood donors and for premarital HCV screening. Also, concordance analysis of OCI in both hepatocytes and PMBCs needs further investigation. If a concordance value close to $100 \%$ is achieved, OCI could be tested for less invasively using only PMBCs, thus avoiding invasive liver biopsy procedures. Here, all six patients tested negative for OCI in both blood and liver tissue.

Table 2. Differences between the three types of occult HCV.

\begin{tabular}{ccccc}
\hline $\begin{array}{c}\text { Occult } \\
\text { HCV } \\
\text { Types }\end{array}$ & HCV RNA & HCV Antibody & Liver enzymes & $\begin{array}{c}\text { HCV RNA } \\
\text { from liver } \\
\text { tissue or } \\
\text { PBMNCs }\end{array}$ \\
\hline Type $\mathbf{1}$ & Negative & Negative & Abnormal & Positive \\
Type $\mathbf{2}$ & Negative & Positive & Normal & Positive \\
Type 3 & Negative & Positive & Abnormal & Positive \\
\hline
\end{tabular}

Table 3. Summary of previous studies on Occult HCV infection in DAA-treated patients with reverse transcription PCR for HCV RNA from hepatocytes.

\begin{tabular}{|c|c|c|c|}
\hline Trial & Characteristics of patients & Liver biopsy & Occult HCV \\
\hline Elmasry $^{8}$ & $\begin{array}{l}14 \text { patients treated with DAA with } \\
\text { abnormal LFT after SVR }\end{array}$ & $\begin{array}{l}\text { 9/14 patients had } \\
\text { liver biopsy }\end{array}$ & $6 / 9(55 \%)$ \\
\hline Gambato $^{9}$ & $\begin{array}{l}\text { - Rx Duration } 14 \text { weeks } \\
\text { - Duration from undetectable } \\
\text { HCV RNA in the serum to } \\
\text { Liver Transplant = } 61 \text { days } \\
\quad(15-118) \text {. } \\
\text { - Nine treated with DAA. }\end{array}$ & $\begin{array}{l}39 \text { patients explanted } \\
\text { liver }\end{array}$ & $\begin{array}{l}\text { - } 26 / 39 \text { positive } \\
\text { HCV in the liver } \\
\text { explant. } \\
\text { - } 6 / 9 \text { positive in } \\
\text { the DAA group }\end{array}$ \\
\hline $\begin{array}{l}\text { The current } \\
\text { study from } \\
\text { Saudi Arabia }\end{array}$ & $\begin{array}{c}6 \text { chronic HCV patients with F1 to } \\
\text { F3 fibrosis, with SVR } 24 \text { weeks } \\
\text { after DAA treatment }\end{array}$ & $5 / 6$ patients & None had occult HCV \\
\hline
\end{tabular}

\section{Conclusion}

In conclusion, results from the current pilot study showed no evidence of OCI in patients from Saudi Arabia in both hepatocytes and PBMNCs, suggesting that occult HCV is a rare phenomenon, espe-

cially among immunocompetent patients postDAA treatment with SVR of 24 weeks. A prospective investigation in a large sample size is warranted, which could further help validate testing for OCI in the future. 


\section{References}

1. Liver EAfSo. EASL Recommendations on Treatment of Hepatitis C 2015. J Hepatol. 2015; 63 (1): 199-236.

2. Aljumah A, Abaalkhail F, Al-Ashgar H, et al. Epidemiology, disease burden, and treatment strategies of chronic hepatitis $\mathrm{C}$ virus infections in Saudi Arabia in the new treatment paradigm shift. Saudi J Gastroenterol. 2016; 22 (4): 269-281.

3. de-Nwulia O, Suarez-Cuervo C, Nelson D, et al. Oral direct-acting agent therapy for hepatitis $\mathrm{C}$ virus infection: A systematic review. Ann Intern Med. 2017; 166 (9): 637-648.

4. Carreño V, Pardo M, López-Alcorocho J, et al. Detection of hepatitis $\mathrm{C}$ virus (HCV) RNA in the liver of healthy, anti-HCV antibody-positive, serum HCV RNA-negative patients with normal alanine aminotransferase levels. J Infect Dis. 2006; 194 (1): 53-60.

5. Radkowski M, Gallegos-Orozco J, Jablonska $\mathrm{J}$, et al. Persistence of hepatitis $\mathrm{C}$ virus in patients successfully treated for chronic hepatitis C. Hepatology. 2005; 41 (1): 106-114.

6. Rezaee-Zavareh M, Hadi R, Karimi-Sari H, et al. Occult HCV Infection: The Current State of Knowledge. Iran Red Crescent Med J. 2015; 17 (11): e34181.

7. Simmons B, Saleem J, Hill A, et al. Risk of late relapse or reinfection with hepatitis $C$ virus after achieving a sustained virological response: A systematic review and meta-analysis. Clin Infect Dis. 2016; 62 (6): 683-694.
8. Elmasry S, Wadhwa S, Bang B, et al. Detection of occult hepatitis $\mathrm{C}$ virus infection in patients who achieved a sustained virologic response to direct-acting antiviral agents for recurrent infection after liver transplantation. Gastroenterology. 2017; 152 (3): 550-3 e8.

9. Gambato M, Pérez-Del-Pulgar S, Hedskog C, et al. Hepatitis $\mathrm{C}$ virus RNA persists in liver explants of most patients awaiting liver transplantation treated with an interferon-free regimen. Gastroenterology. 2016; 151 (4): 633-6.e3.

10. Yousif M, Elsadek Fakhr A, Morad E, et al. Prevalence of occult hepatitis $\mathrm{C}$ virus infection in patients who achieved sustained virologic response to direct-acting antiviral agents. Infez Med. 2018; 26 (3): 237-243.

11. Wang $Y$, Rao $H$, Chi $X$, et al. Detection of residual HCV-RNA in patients who have achieved sustained virological response is associated with persistent histological abnormality. EBioMedicine. 2019; 46:227-35.

12. Donyavi T, Bokharaei-Salim F, Khanaliha K, et al. High prevalence of occult hepatitis C virus infection in injection drug users with HIV infection. Arch Virol. 2019; 164 (10): 2493-2504.

13. Jamshidi $S$, Bokharaei-Salim F, Esghaei $M$, et al. Occult HCV and occult HBV coinfection in Iranian human immunodeficiency virusinfected individuals. J Med Virol. 2020; 92 (12): .3354-3364 